\title{
COMMENTS
}

\section{CORPORATE SOCIAL RESPONSIBILITY THROUGH THE GLOBAL COMPACT: BETWEEN BUSINESS AND SOCIETY}

\author{
EDUARDO GOMES, \\ Fluminense Federal University (Niterói, Brazil) \\ NADJA DE SOUZA, \\ Fluminense Federal University (Niterói, Brazil) \\ LARISA ZAITSEVA, \\ Tyumen State University (Tyumen, Russia) \\ OLGA ABAKUMOVA, \\ Tyumen State University (Tyumen, Russia)
}

DOI: 10.21684/2412-2343-2017-4-4-93-115

Corporate social responsibility of business is becoming an increasingly relevant subject of research in political science, sociology, economics and law. The social responsibility of business is becoming the object of close attention of both governmental and nongovernmental organizations, and the priority of its development is provided at the national, supranational and international levels.

This article considers the political and legal dimensions of the model of corporate social responsibility implemented through the Global Compact as an unprecedented private initiative of the United Nations. A study of the social consequences of the Global Compact offers the opportunity to observe the development of an extremely important initiative: the dissemination of practices and models of corporate social responsibility and the possible implications of this action for society, for business and for the United Nations itself.

Corporate social responsibility, having an internal and external dimension, social and political content, goes far beyond the formal legal aspect. At the same time, states, 
including the BRICS countries, interested in developing corporate social responsibility practices, by legal means, in one way or another contribute to the development of the most promising practices of the social responsibility of business from their point of view. The United Nations pays special attention to the private sector as a promising tool for responding to new problems arising within the international environment. The principles formulated by the United Nations in the Global Compact are reflected and developed in the documents of other international organizations, and then in the programs and regulatory documents of the participating countries, and, of course, in the various codes of large and medium-sized corporations.

Keywords: BRICS countries; corporate social responsibility; Global Compact.

Recommended citation: Eduardo Gomes et al., Corporate Social Responsibility Through the Global Compact: Between Business and Society, 4(4) BRICS Law Journal 93-115 (2017).

\section{Introduction}

In an international context characterized by globalization in the economic, political, social and cultural fields, the United Nations has deepened its relationship with the private sector, stimulating debates which have polarized into two groups: (a) a group which believes that such a relationship can be constructive, since it attracts legitimacy and resources into the organization, strengthening a multilateral governance structure and making it more democratic; and $(b)$ a group which believes that such a relationship is full of risk, since it can delegitimize the organization before the international community, because it treats in an equal manner actors with different economic, political and social weights, which might open the way to accusations of conflicts of interest and favoritism.

In the context of a close association between the UN and the private sector, with an increase in the power of large corporations, Kofi Annan, then SecretaryGeneral of the UN, called upon businessmen to join the UN in a "global compact of shared values and principles, which will give a human face to the global market,"' the so-called Global Compact.

The Global Compact is a voluntary, personal initiative of Kofi Annan, former Secretary-General of the UN, aimed at absorbing the values of Corporate Social Responsibility (CSR) into the organization. The Global Compact now comprises ten principles linked to human rights, labor rights, environmental protection and anticorruption strategies. The central idea is to form networks, by means of an open

Kofi Annan's address to World Economic Forum in Davos, 1 February 1999 (Nov. 14, 2017), available at https://www.un.org/sg/en/content/sg/speeches/1999-02-01/kofi-annans-address-world-economicforum-davos. 
forum, which would guide corporations in implementing the ten principles. Such networks would share experiences, promote social learning, and incentivize the adoption of socially responsible practices.

We believe that because this CSR model has been introduced at such a unique multilateral organization, it bears an unprecedented strong political dimension. Therefore, the study of the social implications of the Global Compact will permit all to see how an extremely important initiative is evolving at the global level: the diffusion of CSR practices and models, and the possible meanings of this diffusion for society, business, and the UN itself.

\section{Theoretical and Conceptual Perspectives on Corporate Social Responsibility (CSR)}

Although the widespread use of CSR was originally linked to changes introduced in the field of management, there is no homogeneous view on the factors that have sustained this diffusion, not on the conceptualization, implications, limits and, in fact, the nomenclature of this kind of practice. Thus, in the last few years, CSR has found fertile ground for its study within the social sciences, mainly from the perspective of the Sociology of Enterprises. ${ }^{2}$ However, the debate is ongoing, and its conclusions are not yet clear. Therefore, to begin with, we will synthesize the main perspectives on CSR. Then we will define what we mean by this practice, and identify its main limitations.

According to Costa, it is possible to identify two general strands within the social sciences that approach CSR. The first one emphasizes that business social actions increase social capital and solidarity links, commitment and reciprocal dependence, which increases human and economic development through the expansion of the participating actors' social circle. It involves horizontal, trust-based networks, along with rules and sanctions, which reduce transaction costs between participating agents. The other one foresees perverse consequences in this "co-responsibilization" between business and societal actors, mainly because of the retreat in the responsibility of the state and the de-politicization and privatization of the public sphere. ${ }^{3}$

Taking the latter view, James K. Rowe sees CSR as a corporate strategy aimed at suppressing popular dissatisfaction. For him, CSR is a private sector auto-regulation strategy: business would counterbalance its interests with those of society, without the need of state intervention in the market. ${ }^{4}$ After analyzing the codes of conduct

2 Ana M. Kirschner, Sociologia da empresa e responsabilidade social das empresas, 202 Nueva Sociedad 133 (2006) (Nov. 10, 2017), also available at http://nuso.org/media/articles/downloads/3343_2.pdf.

3 Eduardo R. Gomes, Dossiê: Responsabilidade Social das empresas, segundo as Ciências Sociais, 18 Antropolítica 11 (2005) (Nov. 10, 2017), also available at http://www.uff.br/antropolitica/revistasantropoliticas/ revista_antropolitica_18.pdf.

4 James K. Rowe, Corporate Social Responsibility as Business Strategy in Ronnie D. Lipschutz \& James K. Rowe, Globalization, Governmentality and Global Politics: Regulation for the Rest of Us? 130 (London and New York: Routledge, 2005). 
voluntarily adopted by firms, Rowe questions their efficacy for the minimization of externalities and concludes that there is a private sector strategy of anticipation to regulation: when firms adopt codes of conduct, they anticipate regulation that would be carried out anyway by means of government agencies, in response to social discontent.

Rowe's main point is that the elaboration and adoption of codes of conduct is a way to avoid excessive restrictions: the diffused voluntary use of socially and environmentally responsible directives by the private sector would counter (inter) governmental codes and would act, by means of private sector organizations, with the aim of responding to threatened reduction in private sector profits. Such movement would work in two fronts: a cultural one (TV, academia, and publicity) and a political one (change in public opinion by means of education and information), in order to produce a certain "consensus" around the need for socially responsible actions by businessmen. This way, people's expectations would be molded and redefined, in sum, transforming popular discontent into capital.

Paoli follows Rowe as she brings into the debate on CSR its political dimension. For her, "business philanthropy" is both an attitude and a discourse that removes conflicts over public citizenship goods from the political arena. According to her, the mobilization of NGOs and the private sector around "social actions" and "ethical conduct" does not presuppose popular participation, once it evolves in private negotiation arenas, in which conflict is curbed. At the same time, such private arenas tend to privilege efficiency-driven technical demands allegedly absent in the public sector. ${ }^{5}$

For Paoli, the diffusion of the idea of "corporate citizenship" is linked to a context of decontractualization produced by the reduction in public policies aimed at the universalization of rights. Such a process, on the other hand, opens the way for private-sector organizations, which are presumed to be more efficient, to act in the public sphere. However, such "non-state public action" will be carried out according to private interests, strengthening the organization's image, which will return to it as a form of profit ("aggregate value"). This way, those who are unknot protected by social security, for example, will have to rely on compensatory measures and business philanthropy.

While for Paoli the economic face of "business philanthropy" appears favorable to private-sector organizations because it "adds value" to products and increases the social power of firms, for other authors, in a more classic/conservative view, CSR may hinder the good performance of firms and the very working of the market economy, for the social function of the private sector was to make the economy work, and to maximize its profits, within the limits of the law. Going beyond this would mean a waste of resources. Therefore, CSR would represent an additional

Célia M. Paoli, Empresas e responsabilidade social: os enredamentos da cidadania no Brasil in Democratizar a democracia: os caminhos da democracia participativa 373 (B.S. Santos (ed.), Rio de Janeiro: Civilização Brasileira, 2003). 
difficulty for a firm. Milton Friedman's article, published in 1970 in "The New York Times Magazine," illustrates just this point. ${ }^{6}$

Friedman believed that CSR clearly harms the structure of a free society, affecting the survival of business as a whole, destroying the market by means of the imposition of exogenous rules, which would represent a kind of "suicidal impulse." Such an impulse results from the unanimity principle which sustains the market economy. The imposition of CSR rules is seen differently by business. For the private sector, such a practice may jeopardize the structure of firms, because it determines other values which, according to Friedman, are not shared:

There are no other values, no "social" responsibilities in any sense other than the shared values and responsibilities of individuals.?

David Henderson agrees with Friedman's argument, as for him the large-scale adoption of CSR practices would tend to hinder the functioning of a market economy, because smaller firms would not be able to bear the costs of social projects. Such firms, whose "public profile is smaller, and worries are more local," would not be ready to compete in such a "socially responsible" environment, for they would not have available resources to invest in social actions, or they would not have the means to adapt to new, more uniform evaluation standards, which in its turn would have a devastating effect on poor countries. ${ }^{8}$

In opposition to Henderson's approach, Grayson and Hodges believe that firms must consider not only their legal and economic obligations, but also their ethical, moral and social obligations in doing business. This would be their way to sustainability. ${ }^{9}$ Along the same line, Patricia Ashley asserts that the responsibility of business in respect of their stakeholders necessarily bears an ethical, moral, and cultural dimension, since,

The very fact of considering that a corporation has certain responsibilities towards its interlocutors, necessarily involves an ethical elaboration, and vice-versa. ${ }^{10}$

6 Milton Friedman, The Social Responsibility of Business is to Increase Its Profits, The New York Times Magazine, 13 September 1970 (Nov. 10, 2017), available at https://www.colorado.edu/studentgroups/ libertarians/issues/friedman-soc-resp-business.html.

7 Id.

8 David Henderson, Misguided Virtue: False Notions of Corporate Social Responsibility 5 (London: Institute of Economic Affairs, 2001) (Nov. 10, 2017), also available at https://iea.org.uk/wp-content/ uploads/2016/07/upldbook126pdf.pdf.

9 David Grayson \& Adrian Hodges, Compromisso Social e Gestão Empresarial: O Que É Necessário Saber para Transformar Questões de Responsabilidade Social em Oportunidades de Negócio 320 (São Paulo: Pubifolha, 2002).

10 Ética e Responsabilidade Social nos Negócios 3 (P.A. Ashley (ed.), $2^{\text {nd }}$ ed., São Paulo: Saraiva, 2005). 
However, changes brought about by popular and market pressures, and by the search for the strengthening of the image of the corporation, make such an ethical dimension even more profound and rigid. Such changes force firms to adopt global standards of cooperation and to respect universally accepted values (liberty, democracy, and human rights), and locally differentiated cultural values, a behavior which tends to be essential for the survival of the firm.

Zairo Cheibub and Richard Locke opened the door to a "third way" by understanding CSR not as a moral matter, but as an economic and political one, and that firms ought to take this responsibility to the extent that it is in their interests to adopt social functions. Thus, Cheibub and Locke understand CSR as a group of actions which go beyond merely abiding by the law or resulting in policies that result from labor negotiations." "To this extent, they think that CSR would only be feasible through a participative management model, in which employees are motivated and contribute to the increase in productivity, responding to both immediate (profit instrumental motivations) and to more long-term (values - moral motivations) goals, from which they title their short article with a question, "Values or interests"?

Cheibub and Locke propose four basic CSR models, structured in two dimensions: (a) beneficiaries of business actions ("stockholders" on one side and "stakeholders" on the other); and (b) motivations that stimulate social actions (morally-driven, longterm goals and instrumentally-driven, short-term goals).

The four CSR models synthesized by them are:

1. Productivism: "basically consists in the maximization of productive goals, within the rule of Law.'12

2. Progressivism: CSR is centered on the instrumental dimension, aimed at a wider public and, even though it reflects the interests of the firm itself, it will take on moral responsibilities to the very extent that it is in the interests of the firm to do so.

3. Philanthropy: the CSR model is situated in the corporation's wider moral dimension, which does not necessarily mean that the corporation expects to obtain benefits from it.

4. Ethical idealism: CSR actions are guided by a moral order, and they aim to produce benefits for the stakeholders.

Regarding the political sense of CSR, Cheibub and Locke explore its complexity and reach the essence of the debate on such practices: the idea that all social actors win with CSR practices, which would represent a serious problem, as the political dimension is not included in the discussion of such phenomenon. The several different social actors must provide citizenship goods, but there is a limitation when

11 Zairo B. Cheibub \& Richard M. Locke, Valores ou interesses? Reflexões sobre a Responsabilidade Social das Empresas in Empresa, empresários e globalização 279 (A.M. Kirschner (ed.), Rio de Janeiro: Relume Dumará; Faperj, 2002).

12 Id. at 281. 
there are no means to require the State to use its mandatory normative action. This implies the increase in the power of some firms, as they take responsibility for functions in the distribution of certain collective goods, which are not demanded as universal rights anymore.

Thus, according to Cheibub and Locke, in a society where corporations start taking the responsibility for the promotion of collective goods, political power adds to their economic power. Such accumulation of power can result in the decrease in the political power of other social actors, and in the dismantling of the public sphere, due to the loss of the comprehension of the meaning of citizenship rights, caused by the absence of debate on the political character of CSR, very much along the lines of what they call a "progressive" model. ${ }^{13}$

To sum up, two dimensions of CSR presented by Cheibub and Locke should be considered. In the first place, an internal dimension, which has to do with the development of fair relationships within the corporation. In this case, a successful corporation necessarily has a participatory style of management, good relationship standards, fair payment, and ethical and respectful treatment. Secondly, an external dimension, characterized not only by the abidance of the law, but also by the engagement in the "public spheres of social decision" and by the abidance "of the rules of the democratic game, not aiming to obtain undue or special advantages,"14 moving beyond what is established by the juridical-normative structure. Last, but not least (for the time being), how to apply all the above to the Global Compact.

\section{The Global Compact: Business and Society}

\subsection{The UN and Its Relationship with the Private Sector}

In a context marked by the increasing power of large transnational corporations, the United Nations has dedicated part of its attention to the private sector as a way to respond to the new challenges posed by the international setting. According to the report produced in 2007 by the Centre for Applied Studies for International Negotiations (CASIN), the relationship between the UN and the private sector is complex and diversified. This relationship goes back to the 1970s, when unsuccessful attempts were made to regulate and modify the behavior of transnational corporations.

The report prepared by CASIN basically points out two perspectives on the relationship between the UN and the private sector. The first recognizes the risks of a close association (and is sustained by NGOs, scholars, and some agencies from within the UN itself, such as the United Nations Research Institute for Social Development - UNRISD). The other seen as "moderate," sees the strengthening of

13 David Vogel, The Market for Virtue: The Potential and Limits of Corporate Social Responsibility 222 (Washington: Brookings Institution Press, 2005).

14 Cheibub \& Locke 2002, at 290. 
this relationship as constructive. This second perspective is mostly represented by business associations and sectors within the UN, suggesting, however, that such relationship must evolve cautiously.

For those that consider the risks and limitations of a close association between the UN and the private sector, favoritism and conflicts of interests are the main issues. The change in the form of relationship has legitimated the corporations as civil society actors, which has been influenced by a number of processes that occurred in the 1980s and 1990s, for instance: (a) structural changes, such as the privatization of the public authority in the international sphere, redefining the frontiers between the public and the private; $(b)$ the period of crisis faced by the UN because of the new challenges posed by the international society, especially the increase in the participation of the private sector; (c) internal economic difficulties; and (d) the new ideological context which favors the increase in the participation of the market in the economy and in governmental matters. ${ }^{15}$

Paine shows that Boutros Boutros-Ghali's term as Secretary-General of the UN, commenced in 1992, defines the end in the monitoring of the operations of transnational corporations. Political pressure by the United States and lobbying groups such as the International Chamber of Commerce generated a process of internal reform that did not favor a mandatory normative structure, but rather a private and voluntary regulation one. Moreover, at the global level, a series of conferences aimed to link the idea of social development to economic development, and private investments began to be seen as means to the reduction of poverty.

Paine and Larrabe's worries are reiterated by Martens and Paul, who add an important point: when multinational corporations become part of organizations such as the UN, they end up acting illegitimately as representatives of the population, because they participate in the decision-making process without having been democratically elected to do so. In this sense, the authors highlight the need of governmental and inter-governmental institutions to maintain the public and institutional character, representing the interests of society as a whole, so that the establishment of globallevel democratic governance structures becomes possible. ${ }^{16}$

According to the report produced by the UN's Joint Special Unit ${ }^{17}$ (1999), the relationship between the UN and the private sector is an old one, being initially based

15 Javier Uncetabarrenechea Larrabe, The New Involvement of Private Sector in the United Nations: Dangerously Eroding the Profit/Non Profit Divide (Nov. 10, 2017), available at http://www.eisa-net. org/be-bruga/eisa/files/events/turin/UNCETABARRENECHEA-PaperUncetabarrenechea.pdf; Ellen Paine, The Road to the Global Compact: Corporate Power and the Battle over Global Public Policy at the United Nations (New York: Global Policy Forum, October 2000).

16 Jens Martens \& James Paul, Comments on the Report of the Cardoso Panel (New York: Global Policy Forum, August 2004).

17 Francesco Mezzalama \& Louis Dominique Ouedraogo, Private Sector Involvement and Cooperation with the United Nations System (Geneva 1999) (Nov. 10, 2017), available at https://www.unjiu.org/en/ reports-notes/archive/JIU_REP_1999_06_English.pdf. 
on commercial relationships, by means of the direct or indirect participation of the private sector as a member or as an observer within normative and standardization structures. The change in the relationship pattern came about with the conception that the private sector can be a partner of the UN in the reduction of poverty, and in the development of a sustainable global economy, which would extend the benefits of globalization to poor countries. Corporations, in their turn, started seeing the UN as a business-friendly institution, because global interdependence and the issues posed by international trade could no longer be handled by any one nation state alone.

Thus, the perspective which sees the participation of "new (business) sectors of civil society" in the UN as something positive is equally based on the idea that, by means of partnerships and the relationship with multi-stakeholders, global governance would be favored and the inter-governmental democratic structured would be strengthened. The opening of the UN to the private sector is seen, then, as something necessary for the very survival and legitimization of the UN, given the opportunities brought about by the participation of more and more active non-state social actors in the international setting.

\subsection{The Global Compact: Principles, Goals, Structure, and Functioning}

In this context of greater proximity between the UN and the private sector, the elaboration of the Global Compact represents the maturation of a project which had first been developed by UN Secretary-General Kofi Annan when he took office in 1997. From that moment on, Mr. Annan started conversations with businessmen, especially at the International Chamber of Commerce and the World Economic Forum.

In 1999, the Secretary-General, in his third visit to the Davos Forum, gave a speech about his intention to develop partnerships between the UN and the private sectorconsidering the objectives of both sides as "mutually supportive" ${ }^{\text {"18 }}$ - and invited businessmen to initiate "a global compact of shared values and principles, which will give a human face to the global market."'19

The intention was to find ways to allow the development of the global economy without the imposition of official restrictions. Two solutions are identified for that: (a) by means of the international arena, corporations can encourage the state to give the UN "the resources and the authority that we need to do our job" and (b) by means of the direct promotion of the shared values in the corporate sphere, of respect for the existing standards and the implementation of new, more advanced environmental and labor standards.

For Kofi Annan, there was a clear interdependence between the UN and the private sector. While the latter provides the former technological knowledge and resources, $\mathrm{UN}$ agencies are ready to assist businessmen and other societal groups in

\footnotetext{
18 Kofi Annan's address to World Economic Forum in Davos, supra note 1.

19 Id.
} 
the political arena, by means of the maintenance of a business-friendly environment. Such an environment depends, in its turn, on the implementation of the ten existing principles and values presented in the Global Compact.

When we analyze the ten principles of the Global Compact, ${ }^{20} \mathrm{Kofi}$ Annan's speech, and other documents and reports produced by the UN, we come to some preliminary conclusions. In the first place, for each principle presented in the Global Compact there is an explanation about its meaning, and about what it refers to. The definition, the means of manifestation, and the international convention which originated the principle are constant characteristics in the exposition of the values presented in the Global Compact. In the sequence, the document presents the importance of the principle for business, the way corporations can get involved with it, and the way it can redound positively to them. For us, this is clear evidence of the instrumental perspective for the adoption of CSR.

The Global Contract is defined as an essentially voluntary program, as it is not a regulatory instrument. It is actually a network, whose center is formed by six UN agencies and by the Global Compact's central office. Five thousand associates ${ }^{21}$ participate in this network today, including individual firms, business associations, NGOs, universities, and others, in more than 120 countries. The possibly underlying aim of this arrangement is to build social legitimacy for the market and corporations, with the participation of not only businessmen, but also governments and civil society organizations, including labor-related ones. The initiative is seen as a way to establish trust and gain social capital, which are considered to be indispensable for the "sustainability of economic development."

20 Here is a list of the ten principles:

"Human Rights

Principle 1: Businesses should support and respect the protection of internationally proclaimed human rights; and

Principle 2: make sure that they are not complicit in human rights abuses.

Labour

Principle 3: Businesses should uphold the freedom of association and the effective recognition of the right to collective bargaining;

Principle 4: the elimination of all forms of forced and compulsory labour;

Principle 5: the effective abolition of child labour; and

Principle 6: the elimination of discrimination in respect of employment and occupation.

Environment

Principle 7: Businesses should support a precautionary approach to environmental challenges;

Principle 8: undertake initiatives to promote greater environmental responsibility; and

Principle 9: encourage the development and diffusion of environmentally friendly technologies.

Anti-Corruption

Principle 10: Businesses should work against corruption in all its forms, including extortion and bribery" (Nov. 10, 2017), available at https://www.unglobalcompact.org/what-is-gc/mission/principles.

${ }^{21}$ Small businesses (those with fewer than 10 employees) are encouraged to apply the ten principles and to participate in the network, but they do not appear in the Global Compact database. 
Based on the search for "accountability, transparency, and the interests of corporations, labor and civil society," the Global Compact aims to guide entrepreneurial activities according to its ten principles. By means of a discussion forum, and the presentation of case studies, it also aims to create a network which will allow participants and stakeholders to meet and get involved, as well as to publicize successful socially responsible corporate practices. Finally, its objective is to stimulate the implementation of the selected principles, incentivizing corporations to line up with them.

Because it is an open forum, maintained through donations, corporations, and other organizations become members of the Global Compact on a voluntary basis. To do so, a CEO must send a letter the Secretary-General of the UN demonstrating his support for and his acceptance of the ten principles. The corporation must inform the public about this acceptance, disseminate it its stakeholders, and include it in its documentation.

Even if there is no measure to check on the implementation of the principles or to sanction their non-fulfillment, a number of mechanisms have been developed to protect the "integrity of the United Nations." For example, one is a governance structure, formed by six entities, which is responsible for strengthening the participants' engagement with the initiative, be it at local or global levels. Other examples are a resolution regarding the use of the UN emblem and the need for corporations to publish annual reports (called Communication on Progress - COP) about their performance in the implementation of the ten principles, which must have at least a brief description available on the corporation's website.

Another aspect worth highlighting is the open access to data, speeches, and documents produced by the Global Compact and by events or networks related to it. Access to all this kind of information suggests the adoption of accessibility and transparency policies, aiming to compensate for the voluntary character of the initiative, and for the non-existence of a mechanism truly capable of monitoring the implementation of the principles.

\section{Views and Reactions to the Global Compact}

From the point of view of the NGOs, the kind of relationship between the UN and the private sector expressed in the Global Compact is a rather suspicious one. Their complaints and worries are synthesized in the report produced by CASIN. In brief, the criticisms of the Global Compact relate to the risk of imbalance generated by such an initiative, as the private sector becomes its main interlocutor, and to the absence of mandatory standards and sanction mechanisms, which would give room to inappropriate use of the UN's values by corporations.

The UN has responded to such criticism by emphasizing that the Global Compact fosters the participation of the NGOs, and that the idea of partnership and mutual benefits is the focus. There is a common understanding that good practices will 
prevail, and this fact would create an incentive for the participation, and, on the other hand, the UN actually does have mechanisms to protect the integrity of the initiative, such as the use of the emblem and the preparation of the annual report (COP).

Another important critical view towards the Global Compact and the close association between the UN and the private sector is the Alliance for a CorporateFree UN, a global network which aims to remove the influence of the private sector on the UN. In 2000, this network initiated the Citizen Compact, an alternative to the Global Compact, whose objective is to establish a normative structure to regulate the action of transnational corporations.

Rowe, whose version of CSR is based on the notion of business strategy, conceives the Global Compact as a way of hushing public dissatisfaction, by mobilizing the legitimacy of the UN. For the author, the close association between the UN and the private sector is carried out, mainly, by means of the action of lobbying groups, such as the International Chamber of Commerce. ${ }^{22}$

Ruggie, who was Kofi Annan's Assistant Secretary-General and senior counselor, saw the Global Compact only as a "second-best solution," once a mandatory and regulatory code could not be implemented, according to him, for three reasons: ( $a$ ) the only countries that would agree to engage in such a process "would be those that are not friendly to business, human rights, or to labor-related or environmental laws"; (b) logistical and financial demands for the UN to monitor transnational corporations and their suppliers would be enormous; and (c) an attempt by the UN in this direction would be strongly opposed by the business community, leading them to take action against regulation. ${ }^{23}$

Thus, although recognizing existing gaps in this model (mainly concerning the lack of sanction and checking mechanisms), Ruggie believes that direct social action, more than legislation, is necessary to make this learning model work. He adds that, when it concerns voluntary action in the field of CSR, there is no agent more capable of supervision than the national governments.

Kell and Ruggie reinforce the perspective according to which Global Compact should not be seen as a code of conduct, but as a learning forum, or a fruitful structure of reference and dialogue. For them, the Global Compact acknowledges that the responsibility for the implementation of such values lies in the first place with national governments, but they believe that such an initiative, when adopted by corporations (and it is incorporated into their mission, their values, and their practices), can bring positive results: (a) at the micro level, in the corporate sphere of action; $(b)$ at the macro level, in the global sphere of decision-making. ${ }^{24}$

22 Rowe 2005.

23 John G. Ruggie, The Theory and Practice of Learning Networks: Corporate Social Responsibility and the Global Compact, 5 Journal of Corporate Citizenship 27 (2002) (Nov. 10, 2017), also available at https:// sites.hks.harvard.edu/m-rcbg/research/j.ruggie_journal.corporate.citizenship_theory.and.practice. of.learning.networks.pdf.

24 Georg Kell \& John G. Ruggie, Global Markets and Social Legitimacy: The Case of the "Global Compact" (Nov. 10, 2017), also available at http://www.yorku.ca/drache/talks/pdf/apd_ruggiekellfin.pdf. 
Kell and Ruggie believe that, at the macro level, the incorporation of universal values by transnational corporations will strengthen the UN's legitimacy, authority, and resources, helping to move forward economic development and the social agenda, favoring the sustainability of the market economy, global commerce, and multilateralism. At the micro level, to the extent that corporations incorporate such global values, they would respond to their internal needs placed by the enormous cultural diversity of their employees, and within their offices. Furthermore, they would be able to count on new business opportunities due to a strengthened image, perhaps along the lines of the understanding of Cheibub and Locke, not to mention Vogel.

For Williams, the main argument sustained by the Global Compact is that, unless corporations adopt a genuine moral stand, globalization will be doomed to failure. The author identifies an increasing preoccupation, among multinational corporations, with the ethical conduct of business, which can be verified through the creation of CSR instruments, of which the Principles of Caux and the Global Sullivan Principles are also examples. ${ }^{25}$

Williams believes that the Global Compact has a chance of becoming an instrument that is more effective than the other existing ones, because it has the visibility, global reach, and the united power of multiple stakeholders that accumulate at the UN. In addition, it holds a view on morality that is twofold: it emphasizes its intrinsic value, and at the same time it highlights its utilitarian aspect, which is favorable to business.

Although the initiative of the UN is seen by the author as a real opportunity and a real effort aimed to emphasize the moral commitments of the corporation, he considers it only a starting point, which is "far from shaping significant changes in the moral values of the global community," but which can originate "a process of learning and improvement, by means of local networks that share universal values." ${ }^{\prime 26}$

\section{Legal Frameworks for the Implementation of the UN Global Compact Principles}

Being a legal act, the UN Global Compact lacks normative character. Nevertheless, its principles may be considered as fundamental ideas that can and should determine the content and direction of the development of legal norms governing the activities of corporations in the humanitarian, social, labor, environmental, and anti-corruption spheres in their broad sense. Considering the principles of the Global Compact as legal, it is possible to single out the international, national, and corporate levels of their legal implementation, implemented in acts of a declarative, mandatory, and recommendatory nature.

25 Oliver F. Williams, The UN Global Compact: The Challenge and the Promise, 14(4) Business Ethics Quarterly 755 (2004).

26 Id. 
It should be noted that the principles presented in the UN Global Compact are not formulated for the first time in it - significant number of international declarations, covenants, and treaties contain similar principles. Such international legal acts include the Universal Declaration of Human Rights (1948), ${ }^{27}$ the International Covenant on Economic, Social and Cultural Rights (1966) ${ }_{1}^{28}$ the Rio Declaration on Environment and Development (1992), ${ }_{1}^{29}$ the ILO Declaration on Fundamental Principles and Rights at Work (1998), ${ }^{30}$ and others. Their main difference is that they form obligations for the participating states, whose public authorities must implement the norms contained in the legal acts through their legislation and the activities of the executive authorities. The possible exception is the ILO Declaration. As the ILO conventions were adopted on the basis of the principle of tripartism, the norms of the Declaration create obligations for the three parties representing the state party to the ILO: governments, national associations of employers (and hence for corporations belonging to designated unions), and national associations of trade unions.

The Global Compact contains principles of conducting business, to which corporations join voluntarily, declaring their willingness to follow them in their daily activities. However, as rightly mentioned above, the Global Compact, as an important UN initiative addressed to the private sector, can be effectively implemented only if there is state protectionism, with the support and approval of the authorities. The main form of public administration that promotes the principles of the Global Compact is the legislation of regulatory legal acts. The corresponding national system of legislation is based on international legal acts mentioned above and those adopted after the Global Compact was created. Apparently, the principles of the Global Compact have had a significant international impact on such acts and interstate documents as the APEC Bangkok Declaration on Partnership for the Future (2003), ${ }_{1}^{31}$ the Treaty on the Eurasian Economic Union (2014), ${ }_{1}^{32}$ the Strategy for BRICS Economic Partnership (2015),

27 Universal Declaration of Human Rights, adopted by Resolution 217 A of the United Nations General Assembly in Paris on 10 December 1948 (Nov. 10, 2017), available at http://www.un.org/en/universaldeclaration-human-rights/.

28 International Covenant on Economic, Social and Cultural Rights, adopted and opened for signature, ratification and accession by General Assembly resolution 2200A (XXI) of 16 December 1966 (Nov. 10, 2017), available at http://www.ohchr.org/EN/Professionallnterest/Pages/CESCR.aspx.

29 ILO Declaration on Fundamental Principles and Rights at Work and Its Follow-up, adopted by the International Labour Conference at its Eighty-Sixth Session, Geneva, 18 June 1998 (Nov. 10, 2017), available at http://www.ilo.org/declaration/thedeclaration/textdeclaration/lang--en/index.htm.

${ }^{30}$ Id.

31 Bangkok Declaration on Partnership for the Future, Bangkok, Thailand, 21 October 2003 (Nov. 10, 2017), available at https://fas.org/asmp/campaigns/MANPADS/APECBangkokDeclaration.pdf.

32 Treaty on the Eurasian Economic Union, Astana, 29 May 2014 (Nov. 10, 2017), available at http://www. un.org/en/ga/sixth/70/docs/treaty_on_eeu.pdf.

33 Strategy for BRICS Economic Partnership, released at the Ufa Summit, 9 July 2015 (Nov. 10, 2017), available at http://www.brics.utoronto.ca/docs/150709-partnership-strategy-en.html. 
Directive 2014/95/EU on Disclosure of Non-Financial Information and Diversity Information, ${ }^{34}$ and many others.

The principles of the Global Compact have an impact on the law-making activities of many international organizations (for example, the ILO, the Unified Energy System), integration groupings, and informal intergovernmental associations (for example, BRICS, APEC), etc., whose activities are aimed at economic integration and the development of common markets. The declarations of these and other international organizations, integration, and informal interstate associations, ILO conventions as well as bilateral and multilateral international treaties, create an obligatory legal framework for subsequent national legal regulation. ILO recommendations, a system of international standards set up by various international institutions, for example, the ISO 26000 International Standard on Social Responsibility, ${ }^{35}$ the GRI Guidelines (on non-financial reporting on the economic, environmental, and social performance of companies in the area of sustainable development), ${ }_{1}^{36}$ the AccountAbility AA1000 (on improving the quality of non-financial reporting) ${ }^{37}$ ISO 14000 series standards (on compliance with environmental requirements in production), SA 8000 standards "Social Accountability 8000 " (on safety and labor conditions improvement ${ }^{38}$ are not mandatory. Nevertheless, they create the most progressive models of the behavior of socially responsible business.

Legislative requirements were introduced for certain enterprises for the necessary social reporting in the European Union. Directive 2014/95/EU on Disclosure of NonFinancial Information and Diversity Information, aimed to increase the transparency of some large enterprises of the EU concerning non-financial information, went into force on 6 December 2014.

"Public-interest" organizations should include in their management report information relating to, as a minimum: environmental matters, social and employeerelated matters, respect for human rights, anti-corruption and bribery matters.

In Russia, the WOC-CSR-2007 standard "Social Responsibility of the Organization. Requirements" was created. The Government of the Russian Federation approved the "Concept for the Development of the National System of Standardization until 2020," which takes into account the best international quality management practices:

34 Directive 2014/95/EU of the European Parliament and of the Council of 22 October 2014 Amending Directive 2013/34/EU as Regards Disclosure of Non-Financial and Diversity Information by Certain Large Undertakings and Groups (Nov. 10, 2017), available at http://eur-lex.europa.eu/legal-content/ EN/TXT/?uri=CELEX\%3A32014L0095.

35 ISO 26000:2010 - Guidance on Social Responsibility (Nov. 10, 2017), available at http://spbtpp.ru/ wp-content/uploads/2015/11/law_national_standart.pdf.

36 G4 Guidelines - Reporting Principles and Standard Disclosures (Nov. 10, 2017), available at https:// www.globalreporting.org/resourcelibrary/GRIG4-Part1-Reporting-Principles-and-StandardDisclosures.pdf.

37 AA1000 Assurance Standard and AA1000 AccountAbility Principles Standard (Nov. 10, 2017), available at https://www.accountability.org/standards/.

38 Social Accountability 8000 (Nov. 10, 2017), available at http://www.iqnet-certification.com/userfiles/ SA8000/2008StdEnglishFinal.pdf. 
- at the national level, the legal support for the development of CSR is carried out by the national legal system (legislation);

- agreements concluded within the framework of public-private or social partnership;

- program documents of non-profit organizations (NGOs) that bring business together;

- collective agreement and corporate legal acts.

Since increasing the social responsibility of business must take into account the interests of such groups as shareholders, investors, government regulatory and supervisory bodies, business partners and suppliers, personnel and professional associations of workers, consumers of goods and services, public organizations, media, representatives of local regional communities, the legal system of the state aimed at regulating the relations between business and these sides can be regarded as a mechanism facilitating the creation of CSR. Such a legal system includes normative legal acts and judicial precedents, depending on the legal system adopted in the state, regulating corporate and civil, labor and social security, administrative and environmental, financial and tax legal relations, as well as antimonopoly and anti-corruption standards.

For example, in the BRICS countries, legal regulation of the activities of economic (trade, business) partnerships and societies is carried out with the help of special legislation. However, in the case of the commitment of the rule of law to the continental system of law, the civil code (Brazil, Russia) refers to sources of legal regulation, and in case of the perception in the common law system approaches (India, South Africa) - a precedent. In China, the general provisions of the graduation law, which do not claim to play the role of a code, still contain prescriptions of a rather general nature, leaving room for the development of special laws that use the terminology and concepts of both systems of law. ${ }^{39}$

If we consider the antimonopoly legislation, which plays a significant role in the foundation of CSR, then in all BRICS countries competition laws are enacted and in force. The Competition Law (1998) of South Africa, the Federal law on the Protection of Competition (2006) in Russia, the Antimonopoly Law of China (2007), the Competition Law of India (2003), and the Brazilian Competition Law (2011) have a number of generally recognized (unified) regulations and norms on, for example, the prohibition against anticompetitive actions and signs of abuse of a dominant position such as the establishment of limits and manipulation of prices for goods (services), the conduct of discriminatory policies with equal counterparts, the imposition of related products and unreasonable contract terms, etc. ${ }^{40}$ This can be regarded as common approaches to the protection of competition as one of the foundations of CSR, although not explicitly named in the UN Global Compact, but a necessary condition for the development of the social responsibility of business.

39 Ksenia M. Belikova et al., Salient Features and Prospects of the Unification of Private Law within the BRICS Countries: Manual. Vol. 1 50-51 (Moscow: Peoples' Friendship University of Russia, 2015).

$40 \quad$ Id. at 328. 
National legislation only creates a basis for the development of CSR with the help of principles, including the principles of the UN Global Compact. However, the real implementation of the CSR principles at the national level is based also on the voluntary will of the business community. The forms of this will depend on which participant's interests in the system of social relations are affected by the activities of the company. In this sense, it is possible to distinguish three levels of "interested persons" and ways of taking into account their interests:

- a state whose interests can be balanced with the interests of socially responsible business through a system of standards, as well as by agreements within the framework of public-private partnership (hereinafter PPP);

- employees, with representatives of whom collective negotiations are held, on the results of which collective agreements are concluded;

- society as a whole, its separate strata, local communities, etc., whose needs can be satisfied in addition to the previously mentioned two methods with the help of charitable and voluntary activities of a commercial company or an entrepreneur.

Today, social scientists, including many from the BRICS countries, are paying close attention to the development of PPP, carrying out relevant research, both in the field of economy ${ }^{41}$ and in the field of law. ${ }^{42}$ Based on a mutually beneficial basis, PPP, however, should be considered as an element of CSR. Regarding the regulatory basis of PPPs, among the BRICS countries only Brazil and Russia have adopted and are implementing PPP laws: in Brazil, the Law on Public-Private Partnership No. 1107 of 2004 and in Russia Federal law No. 224-FZ of 2015 "On Public-Private Partnership, Municipal-Private Partnership in the Russian Federation and Amendments to Certain Legislative Acts of the Russian Federation." In other countries BRICS PPP is regulated by different regulatory documents. In India, PPP is based on the norms of the Indian Constitution. In the Republic of South Africa, PPP is regulated, in addition to Art. 217 of the Constitution, by the laws "On Municipalities" (2000), "On Management of Municipal Finance" (2003), "On Public Finance Management" (1999), and Regulatory Regulation No. 16 of the Ministry of Finance. The main documents of China that determine the opportunities for PPPs are the Law “On Methods of Management of

41 See, for example, Черемная Т.С. ГЧП в странах БРИКС: опыт и перспективы реализации, 5(44) Вестник МГИМО - Университет 190 (2015) [Tatyana S. Cheremnaya, Public Private Partnership in BRICS Countries: Experience and Prospects of Implementation, 5(44) MGIMO Review of International Relations 190 (2015)]; Ковригина С.В. Современный рынок ГЧП в странах БРИКС: анализ и специфика, 11(V.1) Фундаментальные исследования 183 (2016) [Sophia V. Kovrigina, Modern Public Private Partnership Market in the BRICS Countries: Analysis and Specificity, 11(V.1) Basic Research 183 (2016)]; Мамаева Ю.С., Иванченко Л.А. Государственно-частное партнерство: зарубежный опыт и возможности его использования в России, 2 Актуальные проблемы авиации и космонавтики 582 (2015) [Julia S. Mamaeva, Lyudmila A. Ivanchenko, Public Private Partnership: Foreign Experience and Possibilities of Its Use in Russia, 2 Actual Problems of Aviation and Cosmonautics 582 (2015)].

Галиуллина Г.Ф., Кузнецова С.Б., Мингалеева Л.Б. Законодательная база как основа внедрения ГЧП-проектов (опыт зарубежных стран), 3(35) Современные исследования социальных проблем (2014) [Guliya F. Galiullina et al., Legislative Framework as a Basis for the Implementation of PPP Projects (Experience of Foreign Countries), 3(35) Modern Research of Social Problems (2014)]. 
Municipal Public Concessions" (2004) and the Opinion of the State Council (2005). ${ }^{43}$ But despite the different degree of concentration of legislative regulation of PPP, its development has a similar progressive character and ensures the growth of private investments in public infrastructure and other socially significant projects.

Social partnership, as a system of relationships between employees and employers in the person of their representatives, as well as bodies of state power and local selfgovernment, aimed at harmonizing the interests of employers and workers in the world of work, can also be seen as an element of PPP. But only if the collective bargaining is carried out at a level higher than the local (corporate) level and the bodies of state power or local self-government participate in them, acting as spokesmen for the position of the society as a whole or for public authorities whose interests may not coincide either with the interests of entrepreneurs or with the interests of workers (for example, in the regulation of social and labor relations in natural monopolies). The social partnership agreements concluded at the levels above the local level are widespread in Russia. Starting from the General Agreement, concluded at the federal level and having a declarative-programmatic character, and ending with sectoral, regional, and territorial agreements, the third participants of the latter are local selfgovernment bodies, which express the interests of the local community. Still, tripartite agreements are not the rule. Their spread in Russia is explained by the fact that the state "from above" introduced the practice of concluding social partnership agreements, initiating collective negotiations, and participating in them as a third party. This was done with a view to reducing the level of centralized, imperative regulation of labor relations and reducing the share of state guarantees of workers' rights. Today, there is a decrease in the number of tripartite agreements. By virtue of the federal law, only the General Agreement and regional agreements on the minimum wage amount are left to the constituents (in the latter case, the executive body acts as a representative of the budgetary sector employer). Most of the sectoral agreements are bilateral, as are collective agreements concluded in a particular organization.

In Brazil, as in Russia, the issues of collective bargaining and the conclusion of collective agreements are regulated by the codified law-section VI of the Consolidated Labor Law. In China, the Labor Law (1994) provides for the conclusion of a collective agreement at the enterprise; the same issues are established in South Africa by the laws "On Labor Relations" (1995) and "On Basic Conditions of Work" (1997). Codes and laws of these countries establish rules for collective bargaining and the interaction of employers with trade unions on the basis of universal principles consistent with the Global Compact. It is the collective-contractual process, in our view, that reflects the level of CSR at the local level closest to corporation employees.

The spread of the principles of the Global Compact is also promoted by non-profit organizations, including those that unite the business community. In 2004, at the initiative of the Russian Union of Industrialists and Entrepreneurs (RUIE), the Social

43 Cheremnaya 2015, at 195. 
Charter of the Russian Business ${ }^{44}$ was adopted as a set of fundamental principles of socially responsible business practices that are applicable to the daily activities of organizations of any type. The Charter is a document open to accession by any organization that is an employer or promotes its principles. This is a voluntary initiative of Russian business based on the understanding and recognition of the active role of business in social development by representatives of the business community. The Charter is based on a system of principles in the field of economic freedom and social responsibility. In 2007, the Charter was officially recognized as a national document, consistent with the UN Global Compact. ${ }^{45}$ At the same time, 77 companies ${ }^{46}$ have officially joined the United Nations Global Compact in Russia, and the Social Charter of the Russian Business 261 , with a total number of employees of more than 7 million, ${ }^{47}$ which indicates a high potential for growth of the national network of the global agreement in Russia.

According to the data published on the official website of the UN Global Compact, the following number of companies in BRICS countries has joined the Global Compact: Brazil - 735; India - 268; China - 281; Russian Federation - 48; South Africa - 76. ${ }^{48}$ The presented data clearly illustrate the level of relevance for companies in these countries to join the UN global initiative and the degree of involvement in the development of the CSR concept in practice. Differences in the number of affiliated companies in the Russian Federation according to the UN and the Russian network (77 companies in $2016^{49}$ ) are probably due to the fact that the data is updated annually and is related to the fulfillment by the companies of the obligations to publish reports on nonfinancial activities or sustainable development.

\section{Final Considerations}

The extension of the debate on CSR and the multiplication of codes of conduct adopted, mainly, by multinational corporations in the 1990s - have led international organizations such as the UN, OECD, and ILO to consider the subject more seriously, and, this way, to give general directions to CSR practices..$^{50}$ Surprisingly enough, or

44 Social Charter of the Russian Business, adopted by the RUIE Conference in 2004 (Nov. 10, 2017), available at http://eng.rspp.ru/simplepage/860.

45 Корпоративная социальная ответственность: новая философия бизнеса [Corporate Social Responsibility: A New Business Philosophy] 48 (Moscow: Vneshekonombank, 2011) (Nov. 10, 2017), also available at http://www.veb.ru/common/upload/files/veb/kso/ksobook2011.pdf.

46 Глобальный договор ООН в России [United Nations Global Compact in Russia] (Nov. 10, 2017), available at http://www.globalcompact.ru/index/globalnyij-dogovor-oon-v-rossii.html.

47 Социальная хартия российского бизнеса [Social Charter of the Russian Business] (Nov. 10, 2017), available at http://рспп.рф/simplepage/474.

48 United Nations Global Compact (2017) (Nov. 10, 2017), available at https://www.unglobalcompact.org/.

49 United Nations Global Compact in Russia, supra note 46.

50 Ingeborg Wick, Workers' Tool or PR Ploy? A Guide to Codes of International Labour Practice $\left(4^{\text {th }}\right.$ ed., Bonn: Friedrich-Ebert-Stiftung, 2005). 
not, throughout our research we did not find any definition by the Global Compact on the meaning of CSR. No document, website, article, or speech by UN representatives has tried to elaborate the view of the entity about CSR.

We asked ourselves whether the CSR view that is implicitly present in the principles of the Global Compact corresponds to a classic CSR view, or whether it could fit into any of the existing views on the subject. However, it would be unnecessary to compare here the ten principles of the Global Compact with the different perspectives on CSR, and try to frame it into one of them. We believe, nevertheless, that some considerations fit, regarding the classic CSR perspective and the one we adopted in this paper.

Certainly, we do not consider the perspective of the Global Compact as a classic perspective on CSR, in which the responsibility of the corporation would be, in a simplified manner, the generation of profit, creating job opportunities, and paying taxes. However, at the same time, we believe that the UN's implicit understanding of CSR does not fit into the perspective adopted here either, following along with Cheibub and Locke, who sustain that CSR has a double dimension (an internal one, aimed at the development of fair, ethical, and democratic relations within the corporation, and an external one, which aims to strengthen the public sphere of social decisions) and goes beyond the mere abidance of the law and respect for labor negotiations by the corporations..$^{51}$

The ten principles of the Global Compact are based on the Universal Declaration of Human Rights, the International Labor Organization's Declaration on the Fundamental Principles and Rights at Work, the Rio Declaration on Environment and Development, and the United Nations Convention against Corruption, i.e., on international declarations and conventions which, after being internally ratified by the signatory nations, must be abided by, otherwise civil and criminal sanctions may apply. In this sense, the principles introduced by the Global Compact do not advance over the existing legal system in many countries and do not go beyond legal determinations. This might represent a certain ambiguity, because the principles may also introduce some improvements.

The participation of the UN in the debate on CSR adds an important political dimension. We believe that there is a real effort by the UN, by means of the Global Compact, to make sure that corporate actions are in line with ethical and apparently consensual principles. Its decisions, even if they are taken together with the private sector, have greater visibility, relevance, and credibility before international society. For this reason, UN decisions are of interest and attractive for corporations, because, generally speaking, they result in more aggregate value for the image and products of the corporations.

As this political dimension becomes interesting for the corporations, because of its positive effect on profits, the limits of the Global Compact emerge, along with the problems to be confronted by the UN, some of them already presented in this paper. We could mention the elastic nature of the principles, which can be interpreted in 
very restrictive or extensive ways; the voluntary character of the initiative, which does not bind, check, or sanction; and the close association with the private sector.

We believe that the CSR model developed by the UN has not evolved uninterestedly. There has always been an objective which can be related to the very role played by the United Nations. We believe that, by creating such an initiative, the UN has made an effort to act as an interlocutor and a legitimate representative not only of governments, but also of civil society, in which it understands that the private sector belongs.

For the UN, Global Compact certainly means approximation closer association with the private sector more than a search for resources. But it is also a search for power and legitimacy: stronger and stronger business organizations, which have been adding political and social power along with their economic power, constitute important global players. They represent, simultaneously, opportunities and risks which must be cautiously handled. This is where Global Compact fits in, even if it is a "second best solution," as has been previously discussed.

Our analysis of the ten principles of the Global Compact, as well as our analysis of documents, speeches, and arguments presented by the UN in its defense of the adoption of the Global Compact, allow us to conclude that there is a double view on moral - and at this point we follow along Williams s2 $^{52000)}$ - although, in our perspective, an instrumentalist view of these principles tends to dominate.

At first glance, one could easily conclude that the intrinsic valuation of the Global Compact would point to an ethical idealism, as it suggests the construction of a "human face" for the global market by means of the adoption of moral values which derive from universally accepted precepts, and, for this very reason, should be universally put into practice. This way, the UN, as a democratic, multilateral organization, would take over the task of diffusing within the business community such moral values as presented in the Global Compact, supporting initiatives and facilitating dialogue with corporations.

Moving on, it is possible to foresee an instrumentalist motivation for the adoption of such moral values: we have observed that, even if they are apparently universally accepted values, the arguments of the UN constantly emphasize how the acceptance, implementation, and diffusion of such values can produce returns for the firms, i.e., how the adoption of the Global Compact principles can be a source of profits, in the form of either monetary or symbolic gains.

Therefore, there is a double view of morality within the Global Compact: a valuebased view that is intrinsically valid according to principles that are apparently universally accepted, and a progressive and, to a certain extent, utilitarian view on morality, according to which management will be oriented to a wider public, and the firm's moral and social obligations will be taken up to the point where they appear to be of interest to business. ${ }^{53}$

\footnotetext{
2 Williams 2004.

3 Cheibub \& Locke 2002, at 285.
} 
At this point, we see another apparent contradiction. The UN, as a multilateral, humanitarian organization, takes over the responsibility of diffusing certain values and principles, exploring the instrumental dimension of CSR in order to promote its moral dimension, and not the opposite, as would be expected. The arguments for the adoption of the Global Compact are presented as a way to diffuse values which, according to the $\mathrm{UN}$, are universal. This is the ultimate goal of the initiative: the diffusion of values which, however, will not be fulfilled unless it represents for corporations the possibility of obtaining benefits. For this reason, we believe that the instrumental character of the Global Compact will probably not be overcome, because the diffusion of CSR is only possible owing to the perspective of gain foreseen by corporations.

By emphasizing these two sides of CSR, the UN, by means of the Global Compact, acts on two parallel fronts at the global level, in a multi-stakeholder context - and for this reason, we believe that the UN is successful to a certain extent in its initiative (even if it is not free from discontent or criticisms). One front is linked to governments and civil society (business excluded), which demonstrates the effort of the UN to diffuse values that are accepted by international society, increasing the visibility and strengthening the role of the UN. The other front is directly linked to business, indicating how profitable it can be for the private sector to materialize such principles, which is an important incentive for the corporations to adhere to the Global Compact.

As the UN action is carried out on these two fronts, we think it is reasonable to use the expression "to a certain extent." The action of the UN on the second front, the private sector, is a condition for the success of its relationship with governments and civil society, since these will only respect the initiative to the extent that it proves that it can accomplish the Global Compact broadest goals. That is to say, to introduce moral values into the action of the corporations, even if this can only be done in a very limited and not very clear way - just as has been done so far.

Today, we can witness certain efforts of states to promote CSR by special legal tools and stimulation of business. Analysis of the BRICS countries'legislation has proved that the principles of the Global Compact are being implemented at the national level through the existing systems of national legal regulations. Thus, to implement the principles of the Global Compact, international organizations and states should be persistent in their legal policies and work out effective legal instruments. The development of socially responsible business is one of the drivers of social and economic progress. In all the BRICS countries, there is the demand on the part of society for the Global Compact, and there is also the will on the part of the state for its implementation, which together hold the promise of good prospects for its future development.

\section{References}

Cheibub Z.B. \& Locke R.M. Valores ou interesses? Reflexões sobre a Responsabilidade Social das Empresas in Empresa, empresários e globalização 279 (A.M. Kirschner (ed.), Rio de Janeiro: Relume Dumará; Faperj, 2002). 
Ética e Responsabilidade Social nos Negócios (P.A. Ashley (ed.), $2^{\text {nd }}$ ed., São Paulo: Saraiva, 2005).

Lipschutz R.D. \& Rowe J.K. Globalization, Governmentality and Global Politics: Regulation for the Rest of Us? (London and New York: Routledge, 2005).

Martens J. \& Paul J. Comments on the Report of the Cardoso Panel (New York: Global Policy Forum, August 2004).

Paine E. The Road to the Global Compact: Corporate Power and the Battle over Global Public Policy at the United Nations (New York: Global Policy Forum, October 2000).

Paoli M.C. Empresas e responsabilidade social: os enredamentos da cidadania no Brasil in Democratizar a democracia: os caminhos da democracia participativa 373 (B.S. Santos (ed.), Rio de Janeiro: Civilização Brasileira, 2003).

Ruggie J.G. The Theory and Practice of Learning Networks: Corporate Social Responsibility and the Global Compact, 5 Journal of Corporate Citizenship 27 (2002) (Nov. 10, 2017), also available at https://sites.hks.harvard.edu/m-rcbg/research/j.ruggie_ journal.corporate.citizenship_theory.and.practice.of.learning.networks.pdf.

Vogel D. The Market for Virtue: The Potential and Limits of Corporate Social Responsibility (Washington: Brookings Institution Press, 2005).

Wick I. Workers' Tool or PR Ploy? A Guide to Codes of International Labour Practice ( $4^{\text {th }}$ ed., Bonn: Friedrich-Ebert-Stiftung, 2005).

\section{Information about the authors}

Eduardo Gomes (Niterói, Brazil) - Associate Professor, Department of Political Science, Director of the Study Center of the BRICS Countries, Fluminense Federal University (9 Rua Miguel de Frias, Icaraí, Niterói, Rio de Janeiro, 24220-900, Brazil; e-mail: ergomes@id.uff.br).

Nadja De Souza (Niterói, Brazil) - Assistant Researcher, Study Center of the BRICS Countries, Fluminense Federal University (9 Rua Miguel de Frias, Icaraí, Niterói, Rio de Janeiro, 24220-900, Brazil; e-mail: nadja18@yahoo.com.br).

Larisa Zaitseva (Tyumen, Russia) - Head of the Department of Labor Law and Entrepreneurship, Tyumen State University (38 Lenina St., Tyumen, 625000, Russia; e-mail: larisa_zaiceva72@mail.ru).

Olga Abakumova (Tyumen, Russia) - Assistant Professor, Department of Labor Law and Entrepreneurship, Tyumen State University (38 Lenina St., Tyumen, 625000, Russia; e-mail: olgascher@mail.ru). 